\title{
Singlet oxygen damages the function of Photosystem II in isolated thylakoids and in the green alga Chlorella sorokiniana
}

\author{
Faiza Bashir $^{1,2} \cdot$ Ateeq Ur Rehman ${ }^{1} \cdot$ Milán Szabó $^{1,3} \cdot$ Imre Vass $^{1}$ (D)
}

Received: 30 January 2021 / Accepted: 26 April 2021 / Published online: 19 May 2021

(c) The Author(s) 2021

\begin{abstract}
Singlet oxygen $\left({ }^{1} \mathrm{O}_{2}\right)$ is an important damaging agent, which is produced during illumination by the interaction of the triplet excited state pigment molecules with molecular oxygen. In cells of photosynthetic organisms ${ }^{1} \mathrm{O}_{2}$ is formed primarily in chlorophyll containing complexes, and damages pigments, lipids, proteins and other cellular constituents in their environment. A useful approach to study the physiological role of ${ }^{1} \mathrm{O}_{2}$ is the utilization of external photosensitizers. In the present study, we employed a multiwell plate-based screening method in combination with chlorophyll fluorescence imaging to characterize the effect of externally produced ${ }^{1} \mathrm{O}_{2}$ on the photosynthetic activity of isolated thylakoid membranes and intact Chlorella sorokiniana cells. The results show that the external ${ }^{1} \mathrm{O}_{2}$ produced by the photosensitization reactions of Rose Bengal damages Photosystem II both in isolated thylakoid membranes and in intact cells in a concentration dependent manner indicating that ${ }^{1} \mathrm{O}_{2}$ plays a significant role in photodamage of Photosystem II.
\end{abstract}

Keywords Singlet oxygen · Chlorophyll fluorescence imaging · Photoinhibition · Thylakoid membranes · Microalgae

\section{Abbreviations \\ Chl Chlorophyll \\ PSI Photosystem I \\ PSII Photosystem II \\ RB Rose Bengal}

\section{Introduction}

Photosynthesis is a basic process in the biosphere in which green plants, algae and cyanobacteria utilize solar energy to synthesize carbohydrates from carbon dioxide and water see (Renger and Govindjee 1985). The initial, light-dependent steps of the photosynthetic process are performed by four protein complexes embedded in the thylakoid membrane, namely Photosystem II (PSII), Photosystem I (PSI), cytochrome $\mathrm{b} / 6 \mathrm{f}$ complex and the ATP synthase. NADPH

Imre Vass

vass.imre@brc.mta.hu

1 Biological Research Centre, Institute of Plant Biology, Eötvös Loránd Research Network (ELKH), Szeged, Hungary

2 Doctoral School of Biology, University of Szeged, Szeged, Hungary

3 Climate Change Cluster, University of Technology Sydney, Sydney, Australia and ATP, which are produced in the light-dependent reactions are utilized in the so-called dark reactions of photosynthesis, which leads to the fixation of atmospheric $\mathrm{CO}_{2}$ and result in the production of carbohydrates.

Although light is the ultimate driving force of photosynthesis, light at the same time is also a significant damaging agent, which can impair photosynthetic activity. This process is called photoinhibition, whose mechanism remains controversial despite intensive research during the last decades (Jones and Kok 1966; Ohad et al. 1984; Barber and Andersson 1992; Aro et al. 1993; Nishiyama et al. 2006; Vass and Cser 2009; Oguchi et al. 2009; Murata et al. 2012; Tyystjärvi 2013; Zavafer et al. 2017, 2019). The most lightsensitive site in the photosynthetic apparatus is the PSII complex in which electron transport activity is impaired and the D1 (and D2) reaction centre protein is degraded, see (Aro et al. 1993). In addition to PSII, PSI (Sonoike and Terashima 1994; Sonoike et al. 1995; Suorsa et al. 2012; Tiwari et al. 2016; Lima-Melo et al. 2019), as well as the Chl containing light harvesting antenna structures can also be damaged by light (Zolla and Rinalducci 2002; Rinalducci et al. 2004, 2008; Lingvay et al. 2020). The detrimental effects of light linearly depend on light intensity (Tyystjarvi and Aro 1996) and can occur at all light intensities (Keren et al. 1997; Kou et al. 2012), therefore plants have evolved a protective repair mechanism, by which light induced loss of 
photosynthetic activity can be restored. This repair mechanism proceeds via de novo synthesis of the light-damaged D1 (and D2) subunit(s) of PSII (Aro et al. 1993; Nixon et al. 2010; Komenda et al. 2012; Murata and Nishiyama 2018; $\mathrm{Li}$ et al. 2018). Due to competing photodamage and repair processes net loss of PSII activity occurs when the rate of photodamage exceeds the rate of repair.

Although the exact mechanism of photodamage and its repair is not yet fully clarified there is a consensus in the literature that reactive oxygen species (ROS) are involved in the overall photoinhibition process (Barber and Andersson 1992; Anderson and Chow 2002; Nishiyama et al. 2006; Krieger-Liszkay et al. 2008; Pospísil 2009, 2012; Vass 2011; Fischer et al. 2013).

Singlet oxygen $\left({ }^{1} \mathrm{O}_{2}\right)$, which is one of the most important ROS, is an excited state of molecular oxygen which is highly reactive (Ogilby 2010). It damages proteins, lipids and nucleic acids, so it is an important reactive oxygen species (ROS) in biological systems. On the other hand ${ }^{1} \mathrm{O}_{2}$ is also an important signaling molecule (Triantaphylidès and Havaux 2009). It is less stable than triplet oxygen $\left({ }^{3} \mathrm{O}_{2}\right)$, and may be formed in a number of ways; however, the typical way is by energy transfer from the triplet state of a photosensitized pigment or dye molecule (Hirakawa et al. 2011; Fischer et al. 2013). Production of ${ }^{1} \mathrm{O}_{2}$ has been demonstrated in isolated photosynthetic complexes (Macpherson et al. 1993; Hideg et al. 1994a, b; Telfer et al. 1999) and intact photosynthetic systems (Hideg et al. 1998; Flors et al. 2006; Rehman et al. 2013, 2016b). It has also been shown that photolerance in highly light tolerant algal species is accompanied by decreased ${ }^{1} \mathrm{O}_{2}$ production (Treves et al. 2016; Virtanen et al. 2021). However, the exact sites and mechanisms of ROS action in photoinhibition are debated. According to one idea ROS, including ${ }^{1} \mathrm{O}_{2}$, affects only the repair of PSII by inhibiting translation elongation of the $p s b A$ gene, thereby preventing de novo synthesis of photodamaged D1 protein in the cyanobacterium Synechocystis PCC 6803 (Nishiyama et al. 2001, 2004, 2006). Recent results however, have shown that ${ }^{1} \mathrm{O}_{2}$ does not affect the PSII repair process in green algae (Dall'Osto et al. 2019; Barera et al. 2021). Moreover, it has also been proposed that $\beta$-carotene molecules, which are oxidized by ${ }^{1} \mathrm{O}_{2}$ act as signaling agents that induce defense mechanisms that alleviate the effects of PSII photodamage conditions (D'Alessandro and Havaux 2019). Other studies have demonstrated a clear correlation between the rate of ${ }^{1} \mathrm{O}_{2}$ formation and the rate of PSII photodamage in various experimental systems (Rehman et al. 2013; Hakkila et al. 2013, 2014; Bersanini et al. 2014; Sedoud et al. 2014; Treves et al. 2016) pointing to the role of ${ }^{1} \mathrm{O}_{2}$ as an agent that damages directly the function and structure of the PSII complex (Vass and Cser 2009).

One useful approach to assess to role of ${ }^{1} \mathrm{O}_{2}$ in PSII photodamage is the generation of ${ }^{1} \mathrm{O}_{2}$ by externally added photosensitizers. A previous study has compared the ability of different ${ }^{1} \mathrm{O}_{2}$ photosenzitizers (Rose Bengal, Methylene Violet, Neutral Red and Indigo Carmine) to penetrate into plant cells (Kovács et al. 2014). It was concluded that Rose Bengal (RB), which is localized in the chloroplasts and can be excited by green light with only minor effect on photosynthetic electron transport, was the most efficient ${ }^{1} \mathrm{O}_{2}$ producing photosensitizer that resulted in PSII activity loss and D1 protein degradation (Kovács et al. 2014). Similar results were obtained earlier also by using RB infiltrated tobacco leaves (Hideg et al. 2007). However, in these studies very high RB concentrations (100 $\mu \mathrm{M}$, and $1 \mathrm{mM}$, respectively) had to be used to ensure infiltration into the tobacco leaf, and there was no information about the actual level of ${ }^{1} \mathrm{O}_{2}$ inside the cells and in the thylakoid membranes. Therefore, the possibility that unnaturally high ${ }^{1} \mathrm{O}_{2}$ levels caused unspecific PSII damage in these plant studies could not be excluded. It is of note that ${ }^{1} \mathrm{O}_{2}$ production in the presence of low micromolar RB concentrations has been shown to induce growth retardation and specific gene expression in the green alga Chlamydomonas reinhardtii (Leisinger et al. 2001; Fischer et al. 2004), however, direct PSII damage was not demonstrated in these studies.

In the present study we investigated the effect of ${ }^{1} \mathrm{O}_{2}$, when produced by low concentrations of RB, on the photosynthetic activity of isolated spinach thylakoids and intact Chlorella sorokiniana cells. Our data show a RB concentration-dependent loss of PSII activity in both systems (in the 1-10 $\mu \mathrm{M} \mathrm{RB}$ range), which confirm that externally generated ${ }^{1} \mathrm{O}_{2}$ can directly inactivate the PSII complex.

\section{Material and methods}

\section{Biological materials}

Chlorella sorokiniana cells (originating from Culture collection of Autotrophic Organisms (CCALA, Trebon, Czech Republic) were propagated in BG-11 growth medium ( $\mathrm{pH}$ 7.5) and grown at $24{ }^{\circ} \mathrm{C}$ at the irradiance of $60-70 \mu \mathrm{mol}$ photons $\mathrm{m}^{-2} \mathrm{~s}^{-1}$ white light, in $500 \mathrm{~mL}$ flasks containing $200 \mathrm{~mL}$ of BG-11 kept on an orbital shaker. Four days old cultures in the exponential growth phase $\left(\mathrm{A}_{750}\right.$ of $\left.0.2-0.3\right)$ were used for the experiments. The chlorophyll concentration $(\mathrm{Chl} \mathrm{a}+\mathrm{b})$ was determined by a UV-1601 (SHIMADZU) spectrophotometer after extracting the pigments with acetone:DMSO 1:1. Chl a $+\mathrm{b}$ content was calculated according to (Shoaf and Lium 1976). Cells were harvested by centrifugation at $6500 \mathrm{~g}$ for $5 \mathrm{~min}$ and re-suspended in $100 \mathrm{~mL}$ of fresh BG-11 medium at concentration of $5 \mu \mathrm{g}$ of

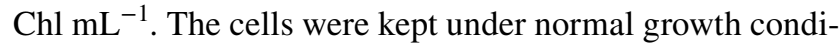
tions for one hour before measurement. 


\section{Thylakoid membrane preparation}

Thylakoid membranes were isolated from fresh spinach leaves as described earlier by (Anderson 1981), and suspended in a buffer solution containing $50 \mathrm{mM}$ tricine ( $\mathrm{pH}=7.5$ ), $7 \mathrm{mM} \mathrm{MgCl} 2,7 \mathrm{mM} \mathrm{CaCl}_{2}$ and $0.3 \mathrm{M}$ Sorbitol. Thylakoid membranes were stored at $-80{ }^{\circ} \mathrm{C}$ for further experiments. Before measurements, thylakoid membranes were resuspended in the same buffer with the $\mathrm{Chl}$ concentration of $5 \mu \mathrm{g}$ of $\mathrm{Chl} \mathrm{mL}^{-1}$.

\section{Experimental procedure for the Rose Bengal assay}

The Rose Bengal (RB) stock solution (500 $\mu \mathrm{M}$ in distilled water) was freshly prepared before each experiment. Samples (in triplicates) were incubated in the presence of 0,1 , 5 and $10 \mu \mathrm{M}$ RB in 24 well plates (Vision Plate ${ }^{\mathrm{TM}} 24$ Well, 4titude, Brooks Life Sciences, U.K.), which were placed in a temperature controlled incubation chamber (temperature was maintained at $24{ }^{\circ} \mathrm{C}$ for Chlorella cells and at $4{ }^{\circ} \mathrm{C}$ for isolated thylakoid membranes, using a water circulation heaterchiller, Julabo). The illumination was provided from the top by a LED array using green light $\left(50 \mu \mathrm{mol}\right.$ photons $\left.\mathrm{m}^{-2} \mathrm{~s}^{-1}\right)$ in combination with white light $\left(190 \mu \mathrm{mol}\right.$ photons $\mathrm{m}^{-2} \mathrm{~s}^{-1}$, green + white irradiance was $240 \mu \mathrm{mol}$ photons $\mathrm{m}^{-2} \mathrm{~s}^{-1}$ ) to excite the RB dye in the $520-550 \mathrm{~nm}$ spectral range, without providing excess excitation to the photosynthetic processes. In Chlorella cells the light treatment was performed both in the absence and presence of $300 \mu \mathrm{g} \mathrm{mL}^{-1}$ lincomycin, which inhibits protein synthesis dependent PSII repair. At the indicated time points, the well plates containing the samples were transferred for chlorophyll fluorescence imaging. The same experiment was also performed in complete darkness, under identical experimental conditions that were applied for light treatment but without applying the LED illumination.

\section{Chlorophyll fluorescence imaging and measurements of the maximum quantum yield of PSII}

Chlorophyll fluorescence of the samples incubated in the well plates was assessed by pulse-amplitude modulated imaging (PAM) MAXI (Imaging-PAM M-series Chlorophyll Fluorometer Heinz Walz GmbH, Germany). The minimum fluorescence in dark adapted state, $\mathrm{F}_{0}$, was measured using a weak measuring light (ML settings $=4$, PPFD $<0.3 \mu$ mol photons $\mathrm{m}^{-2} \mathrm{~s}^{-1}$ ) and maximum fluorescence, $F_{\mathrm{m}}$, was measured by applying a saturation pulse (SP setting $=10$, length: $0.8 \mathrm{~s}$, PPFD: approx. $2000 \mu \mathrm{mol}$ photons $\mathrm{m}^{-2} \mathrm{~s}^{-1}$ ). The maximum quantum yield of PSII was calculated as $F_{\mathrm{v}} / F_{\mathrm{m}}=\left(F_{\mathrm{m}}-F_{0}\right) / F_{\mathrm{m}}$. Samples were dark-adapted for $5 \mathrm{~min}$ before the measurements. The software ImagingWin was applied to select circular areas of interest for individual wells, in which $F_{0}$ and $F_{\mathrm{m}}$ were measured and $F_{\mathrm{v}} / F_{\mathrm{m}}$ was calculated. The ML intensity was adjusted so that the $\mathrm{F}_{0}$ signal did not drop below 0.1, to allow reliable measurements of $F_{0}$ and $F_{\mathrm{m}}$. To ensure homogeneity of the chlorophyll fluorescence signal, an image correction was performed according to the manufacturer, which enabled homogeneous signal intensity across the imaged area. Despite all corrections, some heterogeneity of the incident irradiance in the individual wells always remains, therefore minor spatial variations in the amplitude of $F_{0}$ and $F_{\mathrm{m}}$ cannot be completely avoided. However, this can be compensated by the ratio calculation of maximum quantum yield of PSII $\left(F_{\mathrm{v}} / F_{\mathrm{m}}\right)$, which eliminates the spatial heterogeneity of the amplitude of the basic fluorescence parameters (Schreiber et al. 2007). RB in the thylakoid buffer or in the culture medium did not show any autofluorescence with the $450 \mathrm{~nm}$ ML and SP light source of the PAM system in the $1-10 \mu \mathrm{M}$ concentration range, as RB does not absorb light in this spectral region, therefore, it does not interfere with the $\mathrm{Chl}$ fluorescence imaging measurements.

\section{Oxygen evolution/uptake measurements}

Oxygen evolution and uptake rate was measured using a 4-channel FireStingO2 (FSO2-4) fiber-optical oxygen meter with optode sensors (Robust oxygen probe, OXROB10) (PyroScience GmbH, Aachen, Germany). Oxygen measurements were performed in $1 \times 1 \mathrm{~cm}$ plastic cuvettes, which were placed under identical illumination (green-white light, $240 \mu \mathrm{mol}$ photons $\mathrm{m}^{-2} \mathrm{~s}^{-1}$ ) and incubation conditions that were applied for the multiwell plate experiments. The cuvettes were mounted $45^{\circ}$ onto a plastic platform, to allow homogeneous light penetration to the samples. The optodes were placed into the cuvettes containing the samples and sealed with plastic stoppers. Before measurements, 2-point calibration was performed using air-saturated water and deoxygenated water (with $\mathrm{Na}_{2} \mathrm{~S}_{2} \mathrm{O}_{4}$ ) according to the manufacturers' specifications. $2 \mathrm{~mL}$ cultures with the $\mathrm{Chl}$ content of $5 \mu \mathrm{g} \mathrm{mL}^{-1}$ were loaded into the cuvettes, and measurements in the presence or absence or RB, and in the presence or absence of lincomycin were performed as specified at the relevant sections ('Results' and 'Discussion'). Dark respiration was measured for $5 \mathrm{~min}$ in complete darkness, then oxygen evolution/uptake rate (depending on the applied conditions) was measured for 5 min after switching on the light. To determine ${ }^{1} \mathrm{O}_{2}$ production by $\mathrm{O}_{2}$ uptake, $5 \mathrm{mM}$ Histidine was applied. Oxygen evolution/uptake rates are expressed in $\mu \mathrm{mol} \mathrm{O} \mathrm{mg} \mathrm{Chl}^{-1} \mathrm{~h}^{-1}$.

\section{Statistical analysis}

Statistical analysis was performed using OriginPro (OriginLab Corporation, Northampton, MA, USA). Oneway analysis of variance (ANOVA) and Tukey's post-hoc 
multiple comparison tests $(\alpha=0.05)$ were performed on independent samples to detect statistically significant differences between treatments. Normality tests were performed using Kolmogorov-Smirnov method and the homogeneity of variance test was performed using Levene's method.

\section{Results}

\section{Externally produced ${ }^{1} \mathrm{O}_{2}$ accelerates photodamage of PSII in isolated thylakoid membranes}

To investigate the effect of externally generated ${ }^{1} \mathrm{O}_{2}$ on photosynthetic activity of isolated thylakoid membranes, samples were illuminated in the presence of various concentrations of RB in 24-well plate and PSII activity was quantified by determining the $F_{v} / F_{m}$ values in each well using variable Chl fluorescence imaging. This is a particularly useful approach when PSII activity has to be determined simultaneously in a large number of samples (Schreiber et al. 2007). At the initial time point $(t=0)$, thylakoid membranes imaged in the well plates exhibited homogeneous $F_{\mathrm{v}} / F_{\mathrm{m}}$ values of approx. 0.66-0.74, however, somewhat lower $F_{\mathrm{v}} / F_{\mathrm{m}}$ was observed with increasing RB concentrations (Fig. 1a). $F_{\mathrm{v}} / F_{\mathrm{m}}$ decreased during the light exposure in a RB concentration dependent manner; at $10 \mu \mathrm{M}$ the $F_{\mathrm{v}} / F_{\mathrm{m}}$ essentially dropped to 0 after $30 \mathrm{~min}$ (Fig. 1b). The $F_{\mathrm{v}} / F_{\mathrm{m}}$ values also showed some decrease in darkness, which was more pronounced at higher RB concentrations (Fig. 1c, d). These findings demonstrate that illumination of isolated thylakoids in the presence of RB induces the loss of PSII activity.

The detailed time course of $F_{\mathrm{v}} / F_{\mathrm{m}}$ changes show that PSII activity was gradually decreased in the light-exposed thylakoid membranes (Fig. 2a). Importantly, this effect showed a strong dependence on RB concentration. While in the absence of RB the thylakoids retained ca. $75 \%$ of their initial activity even after $30 \mathrm{~min}$ of light exposure, in the presence $10 \mu \mathrm{M}$ RB a complete loss of $F_{\mathrm{v}} / F_{\mathrm{m}}$ occurred (Fig. 2a). The thylakoids which were treated with 1 and $5 \mu \mathrm{M} R B$ showed an intermediate behavior. The $F_{\mathrm{v}} / F_{\mathrm{m}}$ values showed some decrease even in darkness. This effect was negligible in the absence of RB up to $30 \mathrm{~min}$ (95\% of the initial activity remained), but was enhanced when $\mathrm{RB}$ was also present ( $80 \%$ remaining activity at $10 \mu \mathrm{M} \mathrm{RB}$ after $30 \mathrm{~min}$ ) (Fig. 2b).

To compensate for the slow dark inactivation of PSII activity of thylakoids the $\mathrm{F}_{\mathrm{v}} / \mathrm{F}_{\mathrm{m}}$ data are also shown after normalization of the data obtained in the light to those obtained in the dark (Fig. 2c). This representation shows the extent of PSII activity loss, which is actually caused by externally generated ${ }^{1} \mathrm{O}_{2}$.

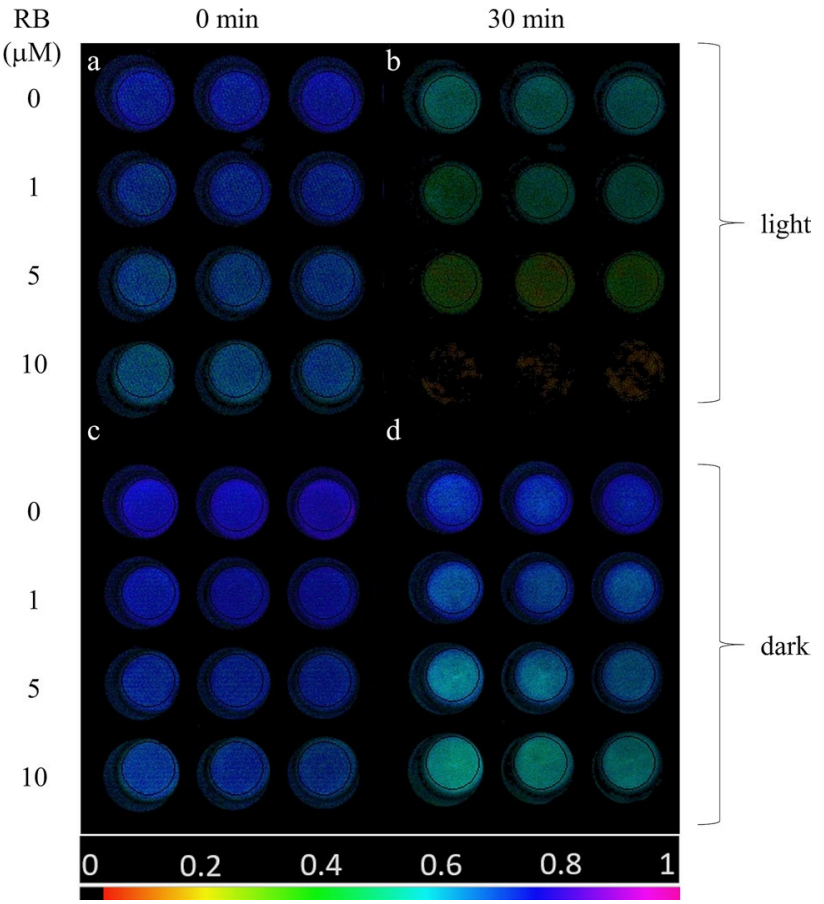

Fig. $1 F_{\mathrm{v}} / F_{\mathrm{m}}$ image of thylakoid membranes illuminated with green + white light (panels $\mathbf{a}, \mathbf{b}$ ) or kept in darkness (c, d) for $0 \mathrm{~min}$ $(\mathbf{a}, \mathbf{c})$ and $30 \mathrm{~min}(\mathbf{b}, \mathbf{d})$. In all panels first row represents control $(0 \mu \mathrm{M} \mathrm{RB})$, second row $1 \mu \mathrm{M} \mathrm{RB}$, third row $5 \mu \mathrm{M} \mathrm{RB}$, fourth row $10 \mu \mathrm{M} \mathrm{RB}(n=3) . F_{\mathrm{v}} / F_{\mathrm{m}}$ values are determined in the selected circular areas of interest. The color bar indicates the relative intensity of $F_{\mathrm{v}} / F_{\mathrm{m}}$

\section{Histidine ameliorates the photodamaging effect of externally produced ${ }^{1} \mathrm{O}_{2}$ in thylakoids}

To check if the observed loss of PSII activity by illumination in the presence of RB is indeed related to ${ }^{1} \mathrm{O}_{2}$-induced damage or not, His was also added to the thylakoid samples. His is a known chemical scavenger of ${ }^{1} \mathrm{O}_{2}$ (Matheson and Lee 1979; Méndez-Hurtado et al. 2012), which can be used in photosynthetic systems without affecting electron transport (Rehman et al. 2013). The addition of $5 \mathrm{mM}$ His together with $5 \mu \mathrm{M}$ RB provided a significant protection against the loss of PSII activity when compared to the effect of RB addition alone (Fig. 3), confirming the involvement of ${ }^{1} \mathrm{O}_{2}$ in PSII damage.

\section{Externally produced ${ }^{1} \mathrm{O}_{2}$ accelerates photodamage of PSII in intact Chlorella cells}

To assess the effect of externally produced ${ }^{1} \mathrm{O}_{2}$ in intact cells first we wanted to have an estimation of the ${ }^{1} \mathrm{O}_{2}$ flux, which is produced by the illumination of RB. This was achieved by using the His-mediated chemical trapping method, which removes dissolved $\mathrm{O}_{2}$ from the medium as a results ${ }^{1} \mathrm{O}_{2}$-induced oxidation of His, which results 

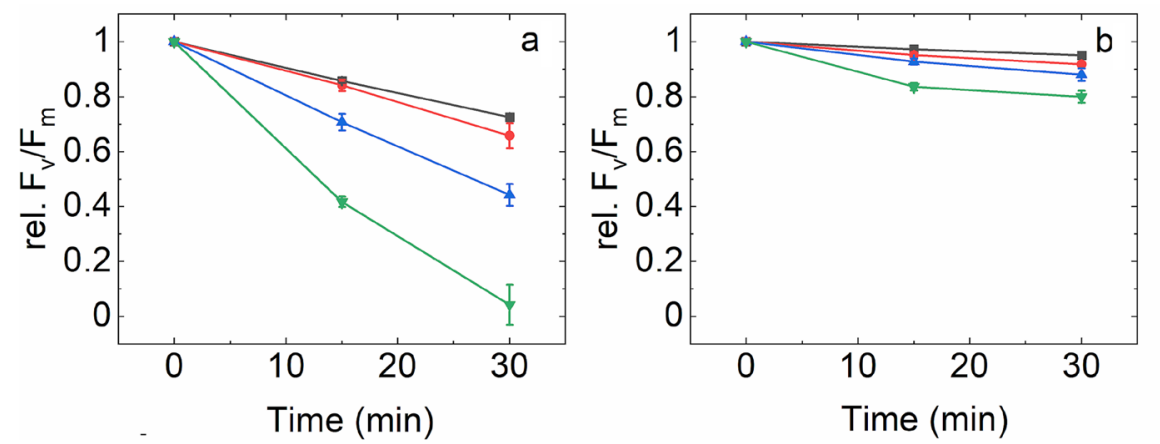

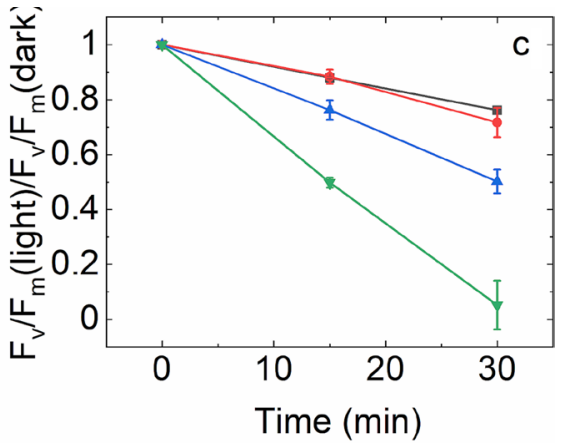

Fig. 2 Effect of RB on the maximum quantum efficiency of PSII $\left(F_{\mathrm{v}} / F_{\mathrm{m}}\right)$ of thylakoid membranes treated with green-white light $(\mathbf{a})$, or kept in dark (b) for the indicated time periods. Panel c represents the ratio of $F_{\mathrm{v}} / F_{\mathrm{m}}$ recorded during the light treatment or dark incuba-

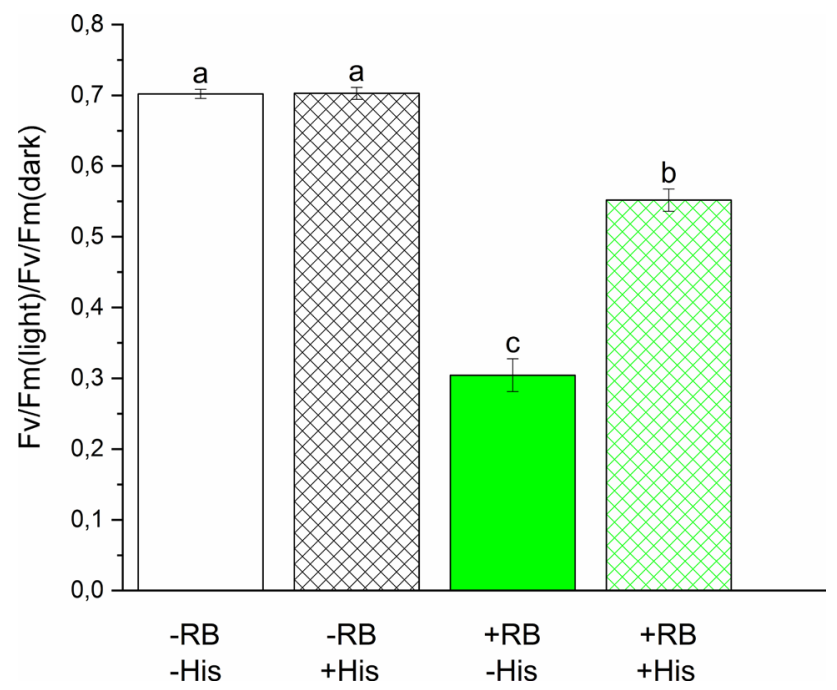

Fig. 3 Effect of histidine on RB-induced loss of PSII activity. Thylakoids were illuminated for $60 \mathrm{~min}$ in the absence and presence of $5 \mu \mathrm{M} \mathrm{RB}$ as in Fig. 1, either without further addition, or in the presence $10 \mathrm{mM}$ histidine. The $F_{\mathrm{v}} / F_{\mathrm{m}}$ values are shown after correction for the change that occurs during dark storage of samples. Different letters above the bars indicate significant differences $(p<0.05)$

in easily measurable $\mathrm{O}_{2}$ uptake (Rehman et al. 2013). Using this approach we showed that the $\mathrm{O}_{2}$ evolution rate decreased in Chlorella cells in the presence of $5 \mathrm{mM}$ His compared to control cells in which His was absent, showing a ca. $52.8 \pm 4.2 \mu \mathrm{mol} \mathrm{O} \mathrm{mg} \mathrm{Chl}^{-1} \mathrm{~h}^{-1}$ rate of ${ }^{1} \mathrm{O}_{2}$ production under the illumination conditions which were applied for the photoinhibition experiments. When Chlorella cells were illuminated in the presence of $1 \mu \mathrm{M}$ $\mathrm{RB}$ the $\mathrm{O}_{2}$ evolution rate was significantly reduced due to chemical trapping of ${ }^{1} \mathrm{O}_{2}$ by proteins and lipids in the cells. Addition of His together with RB resulted in a large $\mathrm{O}_{2}$ uptake (Fig. 4), which shows a ca. $-760.8 \pm 195.5 \mu \mathrm{mol}$ $\mathrm{O}_{2} \mathrm{mg} \mathrm{Chl}^{-1} \mathrm{~h}^{-1}$ rate of ${ }^{1} \mathrm{O}_{2}$ production in the presence of $\mathrm{RB}$. This ${ }^{1} \mathrm{O}_{2}$ production rate in the bulk medium is tion experiment $\left[F_{\mathrm{v}} / F_{\mathrm{m}}\right.$ values in panel (a) were divided by the values on panel (b)]. Thylakoid membranes were incubated in $0 \mu \mathrm{M}$ (black), $1 \mu \mathrm{M}$ (red), $5 \mu \mathrm{M}$ (blue) or $10 \mu \mathrm{M} \mathrm{RB}$ (green)

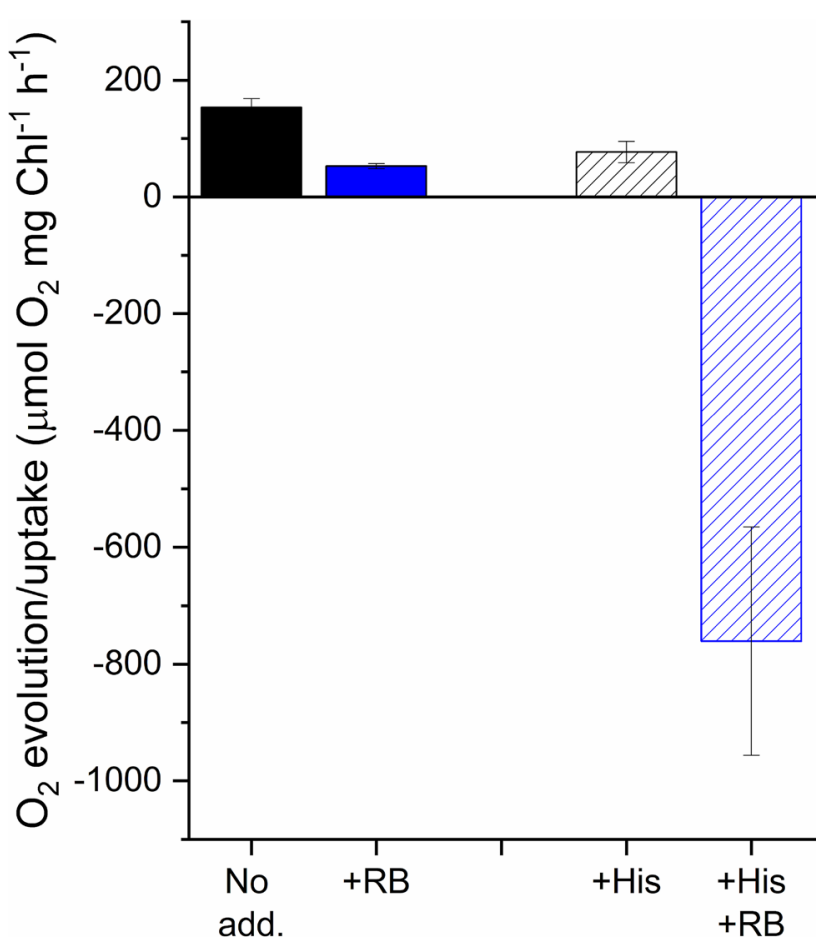

Fig. 4 Oxygen evolution/uptake of Chlorella cells. Black, no treatment, blue, $1 \mu \mathrm{M}$ RB treatment. Closed bars, no His, checked bars, in the presence of $5 \mathrm{mM}$ His

significantly higher than the ${ }^{1} \mathrm{O}_{2}$ rate, which arises from the photosynthetic pigments, i.e. in the absence of RB. However, although RB has been shown to reach chloroplasts in intact leaves (Kovács et al. 2014), its local concentration is most likely lower in the chloroplasts of the Chlorella cells than in the bulk medium. Therefore, the ${ }^{1} \mathrm{O}_{2}$ concentration in the vicinity of PSII is expected to be somewhere between the ambient level, produced by the photosynthetic pigments in the absence of RB, and the bulk level in the culture medium. 
To clarify the effect of externally generated ${ }^{1} \mathrm{O}_{2}$ on PSII activity in vivo, intact Chlorella cells were incubated in light and in darkness in the presence of different concentrations of RB. In intact systems photodamage and repair of PSII proceeds in parallel. To separate these two processes, the experiments were performed both in the absence and presence of lincomycin, which blocks protein synthesis dependent PSII repair and thus allows the investigation of PSII photodamage without the effect of the ongoing repair. At the beginning of the experiment $(t=0 \mathrm{~min})$ the cells exhibited similar $F_{\mathrm{v}} / F_{\mathrm{m}}$ values $(0.63-0.65)$ in the entire plate, indicating that the RB treatment did not affect maximal PSII quantum yield (Fig. 5a). After 60 min light treatment, a RB-concentration dependent decrease in $F_{\mathrm{v}} / F_{\mathrm{m}}$ could be observed, which was more pronounced in the presence of lincomycin (Fig. 5b, well columns 4-6). When the cells were incubated in complete darkness only a minor decrease in $F_{\mathrm{v}} / F_{\mathrm{m}}$ was observed, which was independent of RB concentration (Fig. 5d).

The detailed time course of $F_{\mathrm{v}} / F_{\mathrm{m}}$ values shows that in the absence of lincomycin PSII activity loss showed a tendency to increase after 60 min light exposure in the presence of $\mathrm{RB}$
(Fig. 6a). However, this effect was statistically significant only after $60 \mathrm{~min}$ light exposure (see below, Fig. 7). The presence of lincomycin accelerated PSII damage, which became clearly visible already after $30 \mathrm{~min}$ (Fig. 6a). The enhancement of PSII photodamage showed a clear dependence on RB concentration. While $1 \mu \mathrm{M}$ RB had practically no effect on $F_{\mathrm{v}} / F_{\mathrm{m}}, 5$ and $10 \mu \mathrm{M}$ produced significantly larger $F_{\mathrm{v}} / F_{\mathrm{m}}$ loss after $30 \mathrm{~min}$, than 0 or $1 \mu \mathrm{M}$ RB (Fig. 6a). When Chlorella cells were kept in darkness the $F_{\mathrm{v}} / F_{\mathrm{m}}$ values showed a minor increase followed by a small decrease reaching ca. $97.5 \%$ of the initial PSII activity was kept after 0 min independent of the absence or presence of RB after 60 min (Fig. 6b).

To correct for the small changes of PSII activity in the dark the $\mathrm{F}_{\mathrm{v}} / \mathrm{F}_{\mathrm{m}}$ data are also shown after normalization of the data obtained in the light to those obtained in the dark (Fig. 6c). The changes in $F_{\mathrm{v}} / F_{\mathrm{m}}$ are relatively small in Chlorella cells as compared to those obtained in isolated thylakoids, when the same irradiance and timescale of treatment is applied (Fig. 2). However, after $60 \mathrm{~min}$ light treatment the enhanced decline of $F_{\mathrm{v}} / F_{\mathrm{m}}$ is obvious in the presence of $\mathrm{RB}$, especially in the lincomycin treated cells (Fig. 6c). Although Fig. 6 clearly shows

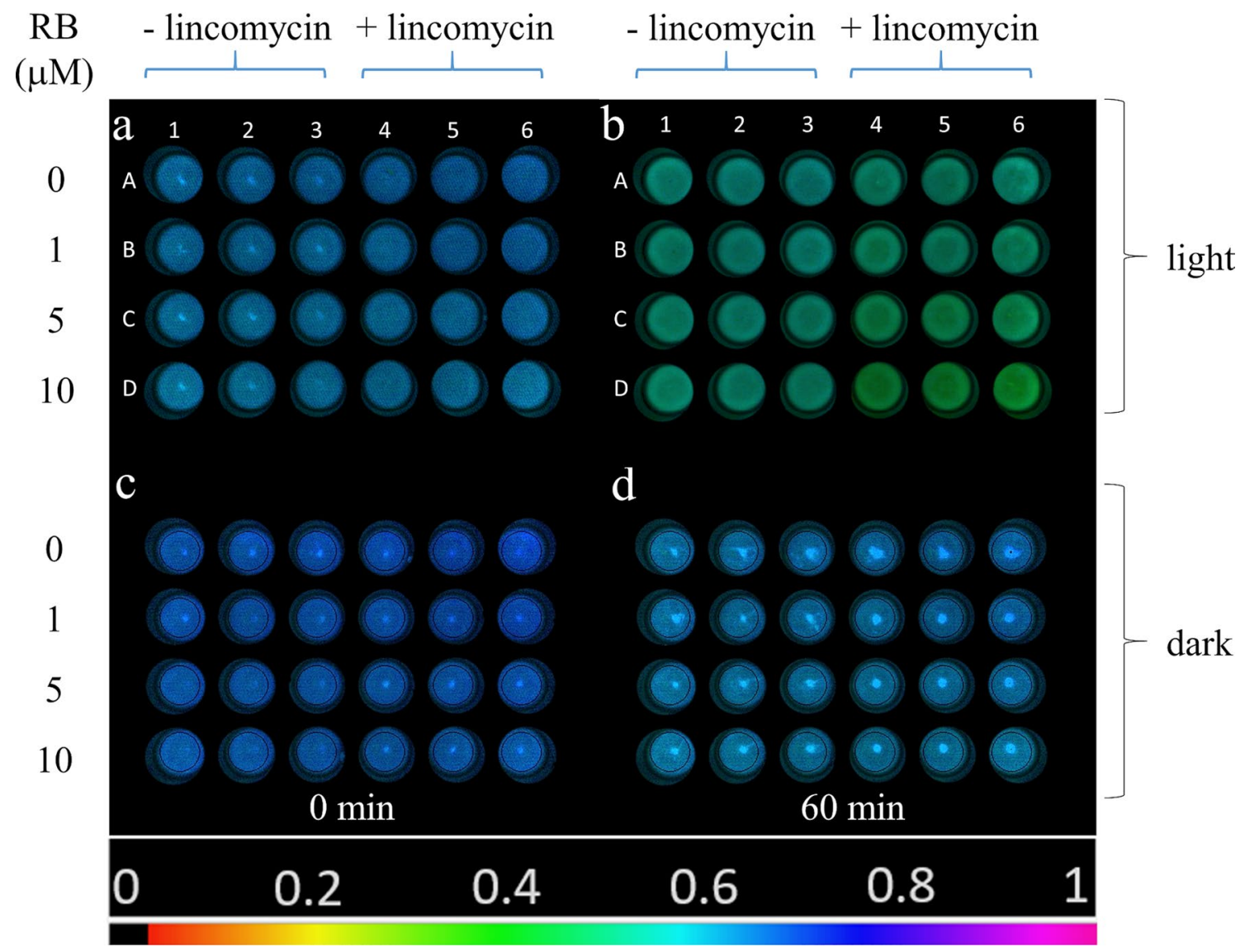

Fig. $5 F_{\mathrm{v}} / F_{\mathrm{m}}$ image of Chlorella sorokiniana cells in the 24 well plates illuminated with green + white light $(\mathbf{a}, \mathbf{b})$ or kept in darkness (c, d) at $0 \mathrm{~min}(\mathbf{a}, \mathbf{c})$ and after $60 \mathrm{~min}(\mathbf{b}, \mathbf{d})$. Wells A1-3: $0 \mu \mathrm{M} \mathrm{RB}$, A4-6: $0 \mu \mathrm{M}$ RB + lincomycin, B1-3: $1 \mu \mathrm{M}$ RB, B4-6: $1 \mu \mathrm{M} \mathrm{RB}+$ lin- comycin, C1-3: $5 \mu \mathrm{M}$ RB, C4-6: $5 \mu \mathrm{M}$ RB+lincomycin, D1-3: $10 \mu \mathrm{M}$ RB, D4-6: $10 \mu \mathrm{M}$ RB + lincomycin. The color bar indicates the relative intensity of $F_{\mathrm{v}} / F_{\mathrm{m}}$ (black: $F_{\mathrm{v}} / F_{\mathrm{m}}=0$, magenta: $F_{\mathrm{v}} / F_{\mathrm{m}}=1$ ) 

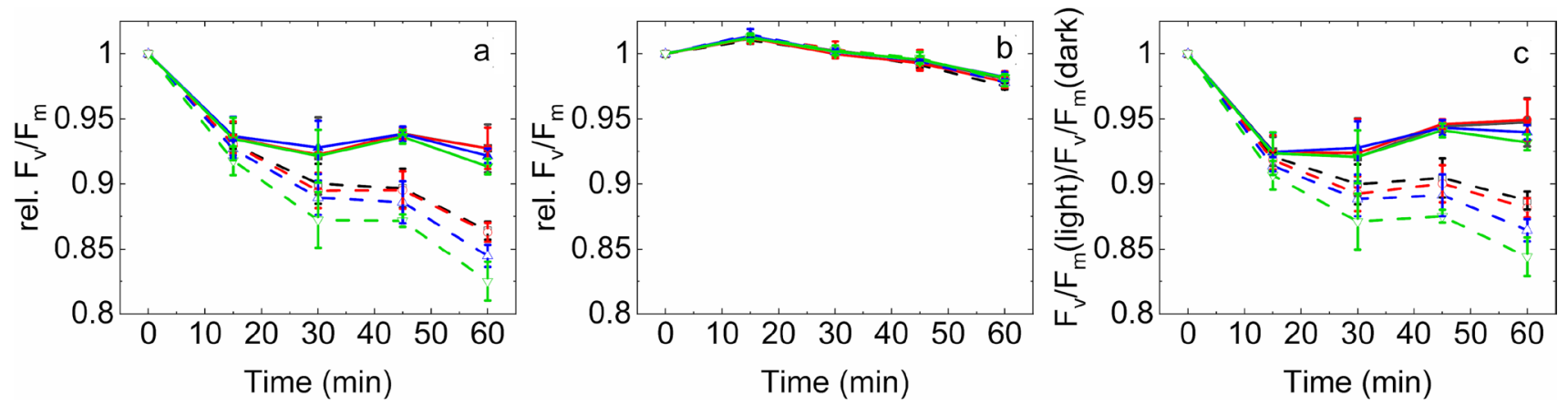

Fig. 6 Effect of RB on the maximum quantum efficiency of PSII $\left(F_{\mathrm{v}} / F_{\mathrm{m}}\right)$ of Chlorella sorokiniana cells treated with green-white light $\left(240 \mu \mathrm{mol}\right.$ photons $\left.\mathrm{m}^{-2} \mathrm{~s}^{-1}\right)(\mathbf{a})$, or kept in dark (b) for the indicated time periods. Panel $\mathbf{c}$ represents the ratio of $\mathrm{F}_{\mathrm{v}} / \mathrm{F}_{\mathrm{m}}$ recorded during the light treatment and dark incubation experiment $\left[F_{\mathrm{v}} / F_{\mathrm{m}}\right.$ values in panel (a) were divided by the values on panel (b)]. Cells were incubated in the presence of $0 \mu \mathrm{M}$ (black), $1 \mu \mathrm{M}$ (red), $5 \mu \mathrm{M}$ (blue) or $10 \mu \mathrm{M}$ (green) RB. Solid lines, cells with no lincomycin, dashed lines, cells in the presence of $300 \mu \mathrm{g} / \mathrm{ml}$ lincomycin
Fig. 7 Maximum quantum efficiency of PSII $\left(F_{\mathrm{v}} / F_{\mathrm{m}}\right)$ of Chlorella sorokiniana cells treated with green-white light $\left(240 \mu \mathrm{mol}\right.$ photons $\left.\mathrm{m}^{-2} \mathrm{~s}^{-1}\right)$ in the presence of $0 \mu \mathrm{M}$ (black), $1 \mu \mathrm{M}$ (red), $5 \mu \mathrm{M}$ (blue) or $10 \mu \mathrm{M}$ (green) $\mathrm{RB}$ for the indicated time periods $(n=9)$. Closed bars, cells with no lincomycin, checkered bars, cells in the presence of $300 \mu \mathrm{g} /$ $\mathrm{ml}$ lincomycin. Different letters above the bars indicate statistically different means, values sharing common letters are not significantly different from one another $(p<0.05)$

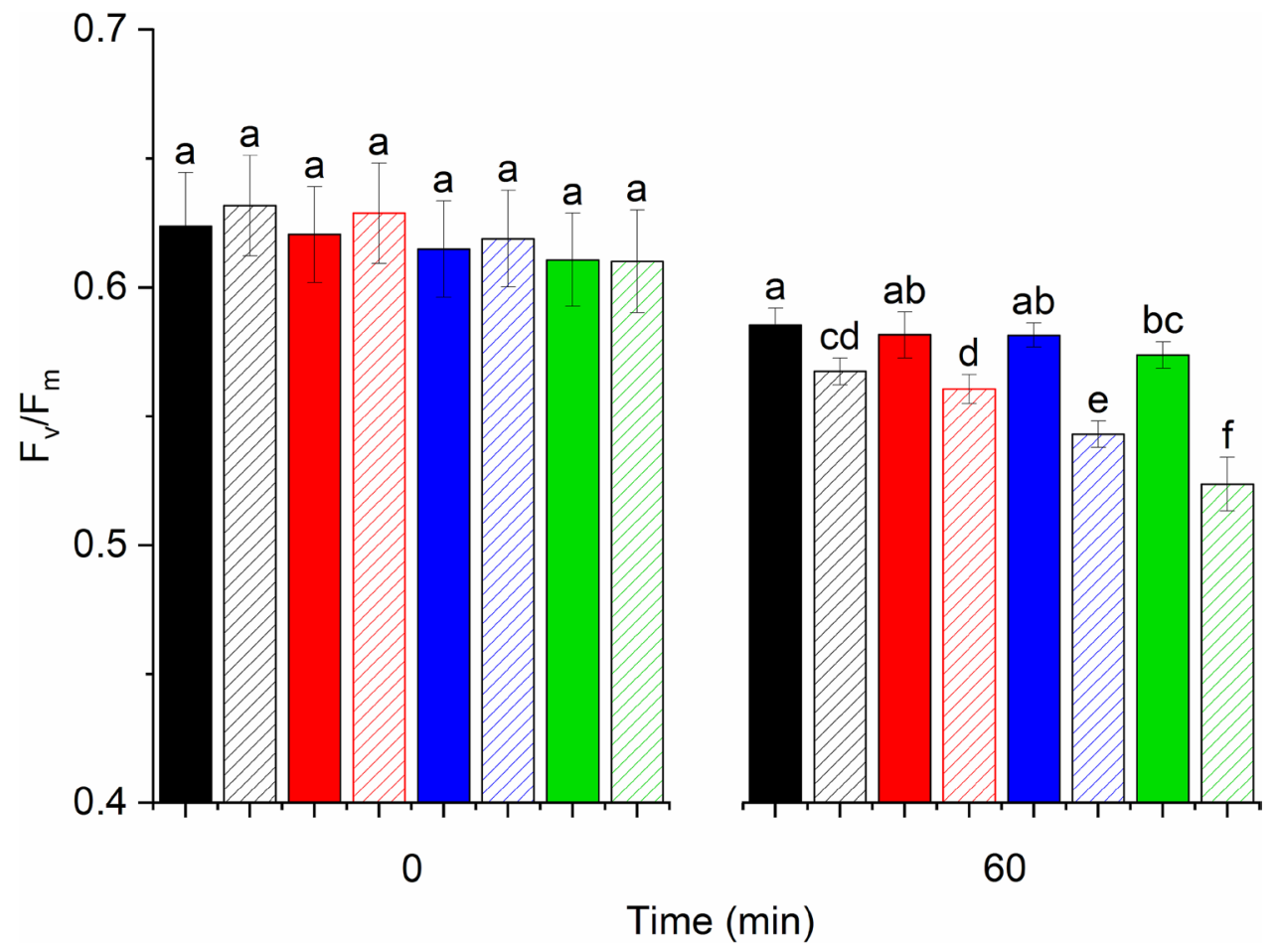

the tendency of cells experiencing larger PSII activity loss in the presence of higher RB concentrations, the extent of these changes was also analyzed for statistically significant differences. As shown in Fig. 7, illumination of the Chlorella cells in the absence of RB resulted in a significant loss of the maximal quantum yield of PSII after 60 min even in the absence of lincomycin, showing that despite the relatively low light intensity photoinhibition of PSII has occurred. The PSII activity loss was enhanced in the presence of lincomycin due to the lack of protein synthesis dependent repair. This effect was further enhanced when RB was present, as an external source of ${ }^{1} \mathrm{O}_{2}$, and the extent of PSII activity loss was increasing practically linearly with increasing concentration of RB. In the absence of lincomycin there was a tendency of increased PSII activity loss in the presence of RB, but the effect was statistically significant only in case of $10 \mu \mathrm{M} \mathrm{RB}$. 


\section{Discussion}

\section{Externally produced ${ }^{1} \mathrm{O}_{2}$ is capable of damaging PSII both in isolated thylakoids and intact Chlorella cells}

It is generally accepted that ${ }^{1} \mathrm{O}_{2}$, as one of the highly reactive ROS forms, is involved in the process of photoinhibition (for reviews see Krieger-Liszkay 2005; Nishiyama et al. 2006; Vass 2011; Tyystjarvi 2013). However, the exact action mechanism of ${ }^{1} \mathrm{O}_{2}$ is debated. The main topic of this debate is whether ${ }^{1} \mathrm{O}_{2}$ can directly damage the PSII complex, or it can inhibit only the protein synthesis dependent repair of PSII. The idea that ${ }^{1} \mathrm{O}_{2}$ is an elicitor of PSII photodamage is supported by various lines of experimental evidence. These findings demonstrate ${ }^{1} \mathrm{O}_{2}$ production in light exposed isolated (Macpherson et al. 1993; Hideg et al. 1994a) and intact (Hideg et al. 1998; Rehman et al. 2013, 2016b) photosynthetic systems. In addition, the correlation between the rate of photodamage and the rate of ${ }^{1} \mathrm{O}_{2}$ production has also been clearly shown (Rehman et al. 2013; Hakkila et al. 2013, 2014; Bersanini et al. 2014; Sedoud et al. 2014). The findings that higher ${ }^{1} \mathrm{O}_{2}$ production rates are accompanied in general with higher PSII photodamage rates do not necessarily prove that ${ }^{1} \mathrm{O}_{2}$ is the cause of PSII damage, since in principle it may happen that photodamaged PSII centers produce more ${ }^{1} \mathrm{O}_{2}$ than the active ones. However, the effect of mutations that enhance or decrease photodamage in parallel with modifications of ${ }^{1} \mathrm{O}_{2}$ production pathways in PSII, which suppress or enhance protective charge recombination routes, respectively (Fufezan et al. 2007; Rehman et al. 2013), provide strong support for the idea that ${ }^{1} \mathrm{O}_{2}$ is indeed an agent that induces or mediates the damage of PSII. This idea is supported also by the correlation of extreme light tolerance and decreased ${ }^{1} \mathrm{O}_{2}$ levels in Chlorella ohadii (Treves et al. 2016).

The idea that ${ }^{1} \mathrm{O}_{2}$ is a direct damaging agent of the PSII complex was challenged on the basis experiments, in which no PSII activity loss was observed when Synechocystis PCC 6803 cells were illuminated in the presence of $\mathrm{RB}$, as an external ${ }^{1} \mathrm{O}_{2}$ source, as well as chloramphenicol as protein synthesis inhibitor (Nishiyama et al. 2001, 2004, 2006). In contrast to these findings infiltration of RB into lincomycin treated intact tobacco leaves accelerated the loss of PSII activity and of the D1 protein (Hideg et al. 2007; Kovács et al. 2014) supporting the idea that external ${ }^{1} \mathrm{O}_{2}$ can damage the structure and function of PSII. However, the high concentration of RB which was applied in these leaf infiltration studies $(1 \mathrm{mM}$ and $100 \mu \mathrm{M}$, respectively) raised the possibility of unspecific damage by the high concentration of externally generated ${ }^{1} \mathrm{O}_{2}$.

Our present data provides evidence that illumination in the presence of RB can indeed damage PSII activity even when relatively low concentrations of $\mathrm{RB}(1-10 \mu \mathrm{M})$ are used, and this damaging effect can be ameliorated in thylakoids by adding histidine, which is a chemical scavenger of ${ }^{1} \mathrm{O}_{2}$ (Fig. 3). These demonstrate that externally generated ${ }^{1} \mathrm{O}_{2}$ inactivates PSII and confirm the validity of earlier leaf infiltration studies in which much larger concentrations $(100-1000 \mu \mathrm{M})$ of RB were used in (Hideg et al. 2007; Kovács et al. 2014). The damaging effect is obviously more substantial in the isolated thylakoids (Figs. 1 and 2) than in the intact Chlorella cells (Figs. 5-7), but even in the latter case the enhancement of PSII activity loss is statistically significant and increases with increasing RB concentrations, especially in the presence of lincomycin, which blocks protein synthesis dependent PSII repair (Fig. 7). ${ }^{1} \mathrm{O}_{2}$ has a very short lifetime and travel distance in a cellular environment (Krasnovsky 1998; Skovsen et al. 2005), therefore it is unlikely that the ${ }^{1} \mathrm{O}_{2}$, which is produced outside the cells could reach the thylakoid embedded PSII complexes in the chloroplasts. The ability of RB to penetrate inside the cells and reach chloroplasts has been shown in tobacco leaves (Kovács et al. 2014). RB can also influence intracellular processes in Synechocystis 6803 (Nishiyama et al. 2004) and Chlorella vulgaris (Dall'Osto et al. 2019) and this is also the case in Chlorella sorokiniana used in the present study. The reason for the weaker inhibition of PSII in the intact Chlorella cells in comparison to the isolated thylakoids should be related to the lower local RB concentration inside the chloroplasts in the algal cells as compared to the bulk medium, and/or the presence of efficient ${ }^{1} \mathrm{O}_{2}$ scavenging processes in the intact system. This idea is supported by the observation that even though a large amount of ${ }^{1} \mathrm{O}_{2}$ was produced at $1 \mu \mathrm{M}$ RB concentrations in the bulk medium (Fig. 4) PSII activity loss was significant only in the higher concentration range of 5-10 $\mu \mathrm{M}$ (Figs. 5, 6).

Similarly to the case of isolated thylakoids we have attempted to check the protective effect of histidine also in the Chlorella cells. However, the results were not conclusive (not shown) most likely due to the relatively small extent of PSII activity loss, which was observed as a result of illuminating Chlorella cells in the presence of RB (Figs. 6, 7). It is also possible that the penetration of histidine to the vicinity of PSII complexes inside the Chlorella cells, where it could exert its protective action, was limited. However, based on the strong protective effect of histidine in thylakoids, we can assume that histidine would ameliorate PSII activity loss in Chlorella as well, provided that it can reach the thylakoids inside the cells.

The loss of PSII activity by externally generated ${ }^{1} \mathrm{O}_{2}$ is in full agreement with previous studies, which showed the impact of ${ }^{1} \mathrm{O}_{2}$ in vitro can be related to the fragmentation of D1 protein, i.e. the scission of peptide bonds in the D1 protein (Lupínková and Komenda 2004; Miyao 1994), and 
consequently inactivation of electron transport (Mishra et al. 1994), and also with the degradation of the D1 protein during illumination of RB infiltrated leaves (Hideg et al. 2007; Kovács et al. 2014). In addition, mass spectrometry analysis of photodamaged PSII showed the presence of oxidized amino acid residues both at the acceptor and donor sides of the PSII reaction center complex, which demonstrates the damage of the D1 and D2 proteins by reactive oxygen species (Kale et al. 2017; Zhou et al. 2021).

\section{Reasons for contradiction with earlier data}

Considering the contradiction of results in the present study concerning the damaging effect of externally produced ${ }^{1} \mathrm{O}_{2}$ with those of earlier studies by Nishiyama and coworkers in which no effect of RB induced ${ }^{1} \mathrm{O}_{2}$ on PSII damage rate was observed (Nishiyama et al. 2004) it is important to clarify the possible causes of this disagreement. There are four main differences of the experimental conditions in the present study and in the previous investigation (Nishiyama et al. 2004): (i) Isolated spinach thylakoids and Chlorella sorokiniana cells vs. the cyanobacterium Synechocystis PCC 6803. (ii) Relatively weak $\left(240 \mu \mathrm{mol}\right.$ photons $\left.\mathrm{m}^{-2} \mathrm{~s}^{-1}\right)$ green dominated light to specifically excite RB without significant excitation of Chl vs. strong illumination by white light $\left(1500 \mu \mathrm{mol}\right.$ photons $\left.\mathrm{m}^{-2} \mathrm{~s}^{-1}\right)$. (iii) Lincomycin vs. chloramphenicol as protein synthesis inhibitor in the present study. (iv) PSII activity was assessed here by Chl fluorescence imaging to determine $F_{\mathrm{v}} / F_{\mathrm{m}}$ vs. $\mathrm{O}_{2}$ evolution measurements by a Clark type oxygen electrode by Nishiyama et al. (Nishiyama et al. 2004). In the following section we discuss the significance of these differences.

\section{Experimental objects}

In order to study the effect of externally produced ${ }^{1} \mathrm{O}_{2}$ on PSII activity it has to be made sure that the added photosensitizer, in this case RB, can reach the vicinity of the target, i.e. the PSII complex. This can be easily achieved in the aqueous suspension of isolated thylakoid membranes. Therefore, we choose thylakoids as one of our experimental object. The previous work (Nishiyama et al. 2004) was performed with the cyanobacterium Synechocystis 6803, which is undoubtedly a very useful and widely used model organism for photosynthesis and photoinhibition studies. However, the lack of RB-induced PSII damage might have been caused by a limited penetration of RB inside the Synechocystis cells limiting the amount of ${ }^{1} \mathrm{O}_{2}$ in the vicinity of the thylakoid membranes. Therefore, we choose the green alga Chlorella sorokiniana, since penetration of RB into Chlorella cells has been demonstrated in the closely related Chlorella vulgaris species (Dall'Osto et al. 2019). Since the damaging effect of RB-mediated ${ }^{1} \mathrm{O}_{2}$ production was clearly seen in both the isolated thylakoids (Figs. 1-3) and in the Chlorella cells (Figs. 5-7), one factor in the lack of detection of PSII activity loss in Synechocystis (Nishiyama et al. 2004) is probably the limited reach of RB into the vicinity of the thylakoid embedded PSII complexes in this cyanobacterium. It is of note that some ${ }^{1} \mathrm{O}_{2}$ was certainly produced by illumination of RB in the Synechocystis cells as shown by the inhibition of psbA mRNA elongation, which is a crucial step of the D1 protein synthesis dependent PSII repair (Nishiyama et al. 2004). However, the solubility of RB in water is much better than in organic solvents, therefore the RB sensitized ${ }^{1} \mathrm{O}_{2}$ can more easily reach the site of $\mathrm{D} 1$ synthesis, which takes place in ribosomes attached to the cytosolic surface of the thylakoid membrane (Tyystjarvi et al. 2001), than the hydrophobic inner parts of the thylakoids where most of the functional components of the PSII complex are located.

\section{Illumination protocol}

We used relatively low light intensity $(240 \mu \mathrm{mol}$ photons $\mathrm{m}^{-2} \mathrm{~s}^{-1}$ ) with a significant contribution in the green spectral range that excites specifically $\mathrm{RB}$, without driving the photosynthetic electron transport. As consequence we could avoid strong photoinhibition by photosynthetically active light and the damaging effect to PSII was induced mostly by the RB generated ${ }^{1} \mathrm{O}_{2}$. In contrast, Nishiyama et al. (Nishiyama et al. 2004) used very strong $\left(1500 \mu \mathrm{mol} \mathrm{m}^{-2} \mathrm{~s}^{-1}\right)$ visible light, which in itself induced extensive photodamage of PSII, and combined this strong illumination with RB addition. As a consequence, the effect of RB addition on the photodamage rate was most likely relatively small, which could be left unnoticed. Actually, green illumination, which selectively excites RB was also used in the work by Nishiyama et al. (Nishiyama et al. 2004), but only for assessing the ${ }^{1} \mathrm{O}_{2}$ effect on the repair process (i.e. in the absence of protein synthesis inhibitor). It is a puzzle why this straightforward approach was not used for assessing the ${ }^{1} \mathrm{O}_{2}$ effect on the photodamage rate (i.e. in the presence of protein synthesis inhibitor)?

\section{Protein synthesis inhibitors}

To separate the processes of photodamage and repair of PSII intact cells have to be treated with a protein synthesis inhibitor. In photoinhibition studies the most popular protein synthesis inhibitors are lincomycin and chloramphenicol (Kodru et al. 2020). Their application is based on the assumption that they are not interacting with photosynthetic electron transport processes. Unfortunately, this is not the case for chloramphenicol, which has been shown to act as electron acceptor in PSI and reduce oxygen to reactive superoxide (Okada et al. 1991). More recently it was shown that chloramphenicol accepts electrons not only from PSI, but also from PSII (Rehman et al. 2016a), and also that this effect 
artificially enhances PSII photodamage via superoxide production in intact Synechocystis cells if chloramphenicol is applied above $100 \mu \mathrm{g} \mathrm{mL}^{-1}$ concentration (Kodru et al. 2020). Therefore, in the present study lincomycin was used in contrast to the work by Nishiyama et al. in which $200 \mu \mathrm{g} \mathrm{mL}^{-1}$ chloramphenicol was applied (Nishiyama et al. 2004). Similarly, to the effect of strong light the presence of high chloramphenicol amount could enhance the photodamage rate in the earlier study (Nishiyama et al. 2004) decreasing the chance to detect the RB effect.

\section{PSIl activity measurements}

In the presence of RB illumination of the samples produce a large amount of ${ }^{1} \mathrm{O}_{2}$, which can chemically react with, i.e. oxidize, proteins, lipids and other organic material in its environment. This oxidation results in $\mathrm{O}_{2}$ uptake that decreases the apparent $\mathrm{O}_{2}$ evolution rate detected by the Clark type electrode (see the decreased $\mathrm{O}_{2}$ rate in the presence of $1 \mu \mathrm{M}$ RB in Fig. 6). Since in the previous Synechocystis study (Nishiyama et al. 2004) 2 and $10 \mu \mathrm{M}$ RB was used the modification of the $\mathrm{O}_{2}$ evolution rate must have been much larger than that we observed here, unless RB was washed out from the cells before the $\mathrm{O}_{2}$ evolution assay. Although there is no indication for such a precaution in the Nishiyama paper this was most likely the case, otherwise the $\mathrm{O}_{2}$ evolution rate must have been very small even in the non-photoinhibited cells, which is not noted in the paper. The main reason for using $\mathrm{Chl}$ fluorescence imaging method in our present study was that it made possible to perform all treatments and PSII activity measurements under exactly the same experimental conditions. In addition, the Chl fluorescence imaging method is not affected at all by the ${ }^{1} \mathrm{O}_{2}$ induced $\mathrm{O}_{2}$ uptake problem. Therefore, using Chl fluorescence imaging vs. $\mathrm{O}_{2}$ evolution measurements does not seem to be a crucial factor in the contrasting results.

Based on the above comparison of experimental conditions our conclusion is that the lack of detecting the RBinduced enhancement of PSII photodamage rate in the previous study (Nishiyama et al. 2004) was most likely the consequence of multiple effects: (i) The limited ability of ${ }^{1} \mathrm{O}_{2}$ produced by $\mathrm{RB}$ to reach the thylakoid embedded functional components of the PSII decreased the chance of detecting PSII activity loss. (ii) The application of strong visible light instead of selective excitation of RB for the photodamage experiments together with using high chloramphenicol concentration enhanced the photodamage rate, which could easily mask the relatively small enhancement of ${ }^{1} \mathrm{O}_{2}$-induced PSII damage. In our study these technical problems were eliminated by selective excitation of RB and by the application of lincomycin as protein synthesis inhibitor, that does not interfere with PSII electron transport and made possibly the detection of ${ }^{1} \mathrm{O}_{2}$-induced PSII activity loss not only in the isolated thylakoids, but also in the intact Chlorella cells.

\section{Conclusions}

We provided clear experimental evidence that ${ }^{1} \mathrm{O}_{2}$ when generated by the externally added photosensitizer RB induces the loss of PSII activity both in isolated thylakoids and intact Chlorella cells, which are incapable of PSII repair. These data demonstrate that ${ }^{1} \mathrm{O}_{2}$ when produced by an external source, outside of the photosynthetic apparatus, is capable of direct inactivation of PSII. Our results also provide support for the idea that ${ }^{1} \mathrm{O}_{2}$ could act as an inducer of photodamage in native photosynthetic systems when it is produced by chlorophylls and other pigments (Vass and Cser 2009), in agreement with the proposal that light absorption in the catalytic Mn cluster cannot be solely responsible for the inactivation of PSII (Ohnishi et al. 2005), and other, Mn-independent damage mechanisms should also be considered (Oguchi et al. 2009, 2011; He et al. 2015; Iermak et al. 2020).

Author contributions F Bashir performed most of the experiments. AU Rehman participated in the thylakoid experiments and supervised the work of F Bashir in the initial phase of the study. M Szabo directed the well plate-based imaging experiments. I Vass conceived the idea and wrote the manuscript with the contribution of all coauthors.

Funding Open access funding provided by ELKH Biological Research Center. The work was supported by the National Research, Development and Innovation Office (NKFIH K 116016). M.S. was supported by the Hungarian Academy of Sciences, MTA Premium Postdoctoral Research Program (grant ID: PREMIUM-2017-38) and by the National Research, Development and Innovation Office (grant ID: NKFIH FK 128977).

Data availability All data presented are available in the form of figures, and tables in the main text.

\section{Declarations}

Conflict of interest The authors have no conflicts of interest to declare that are relevant to the content of this article.

Open Access This article is licensed under a Creative Commons Attribution 4.0 International License, which permits use, sharing, adaptation, distribution and reproduction in any medium or format, as long as you give appropriate credit to the original author(s) and the source, provide a link to the Creative Commons licence, and indicate if changes were made. The images or other third party material in this article are included in the article's Creative Commons licence, unless indicated otherwise in a credit line to the material. If material is not included in the article's Creative Commons licence and your intended use is not permitted by statutory regulation or exceeds the permitted use, you will need to obtain permission directly from the copyright holder. To view a copy of this licence, visit http://creativecommons.org/licenses/by/4.0/. 


\section{References}

Anderson JM (1981) Consequences of spatial separation of Photosystem 1 and 2 in thylakoid membranes of higher plant chlosroplasts. FEBS Lett 124:1-10

Anderson JM, Chow WS (2002) Structural and functional dynamics of plant Photosystem II. Philos Trans R Soc B-Biol Sci 357(1426):1421-1430. https://doi.org/10.1098/rstb.2002.1138

Aro E-M, Virgin I, Andersson B (1993) Photoinhibition of Photosystem II. Inactivation, protein damage and turnover. Biochim Biophys Acta 1143:113-134

Barber J, Andersson B (1992) Too much of a good thing: light can be bad for photosynthesis. Trends Biochem Sci 17:61-66

BareraDall'Osto SL, Bassi R (2021) Effect of lhcsr gene dosage on oxidative stress and light use efficiency by Chlamydomonas reinhardtii cultures. J Biotechnol. https://doi.org/10.1016/j.jbiot ec. 2020.12 .023

Bersanini L, Battchikova N, Jokel M, Rehman AU, Vass I, Allahverdiyeva Y, Aro E-M (2014) Flavodiiron protein Flv2/Flv4-related photoprotective mechanism dissipates excitation pressure of PSII in cooperation with phycobilisomes in cyanobacteria. Plant Physiol 164(2):805-818

D'Alessandro S, Havaux M (2019) Sensing $\beta$-carotene oxidation in Photosystem II to master plant stress tolerance. New Phytol 223(4):1776-1783. https://doi.org/10.1111/nph.15924

Dall'Osto L, Cazzaniga S, Guardini Z, Barera S, Benedetti M, Mannino G, Maffei ME, Bassi R (2019) Combined resistance to oxidative stress and reduced antenna size enhance light-to-biomass conversion efficiency in Chlorella vulgaris cultures. Biotechnol Biofuels 12(1):221. https://doi.org/10.1186/s13068-019-1566-9

Fischer BB, Hideg É, Krieger-Liszkay A (2013) Production, detection, and signaling of singlet oxygen in photosynthetic organisms. Antioxid Redox Signal 18:2145-2162

Fischer BB, Krieger-Liszkay A, Eggen RIL (2004) Photosensitizers neutral red (Type I) and rose bengal (Type II) cause lightdependent toxicity in Chlamydomonas reinhardtii and induce the Gpxh gene via increased singlet oxygen formation. Environ Sci Technol 38(23):6307-6313. https://doi.org/10.1021/es049 $673 y$

Flors C, Fryer MJ, Waring J, Reeder B, Bechtold U, Mullineaux PM, Nonell S, Wilson MT, Baker NR (2006) Imaging the production of singlet oxygen in vivo using a new fluorescent sensor, Singlet Oxygen Sensor Green ${ }^{\circledR}$. J Exp Bot 57:1725-1734

Fufezan C, Gross CM, Sjödin M, Rutherford AW, Krieger-Liszkay A (2007) Influence of the redox potential of the primary quinone electron acceptor on photoinhibition in Photosystem II. J Biol Chem 282:12492-12502

Hakkila K, Antal T, Rehman AU, Kurkela J, Wada H, Vass I, Tyystjärvi E, Tyystjärvi E (2013) $\Delta$ sigCDE, a mutant of Synechocystis sp. PCC 6803 having SigB as an only functional group factor, is vulnerable to oxidative stress but resistant against photoinhibition. Biochim Biophys Acta 54(11):1780-1790

Hakkila K, Antal T, Rehman AU, Kurkela J, Wada H, Vass I, Tyystjärvi E, Tyystjärvi T (2014) Oxidative stress and photoinhibition can be separated in the cyanobacterium Synechocystis sp. PCC 6803. Biochim Biophys Acta 1837:217-225

He J, Yang WQ, Qin L, Fan DY, Chow WS (2015) Photoinactivation of Photosystem II in wild-type and chlorophyll b-less barley leaves: which mechanism dominates depends on experimental circumstances. Photosynth Res 126(2-3):399-407. https://doi.org/10. 1007/s11120-015-0167-0

Hideg É, Kálai T, Hideg K, Vass I (1998) Photoinhibition of photosynthesis in vivo results in singlet oxygen production. Detection via nitroxide-induced fluorescence quenching in broad bean leaves. Biochemistry 37(33):11405-11411
Hideg É, Kós PB, Vass I (2007) Photosystem II damage induced by chemically generated singlet oxygen in tobacco leaves. Physiol Plant 131:33-40

Hideg É, Spetea C, Vass I (1994a) Singlet oxygen and free radical production during acceptor- and donor-side-induced photoinhibition. Studies with spin trapping EPR spectroscopy. Biochim Biophys Acta 1186:143-152

Hideg É, Spetea C, Vass I (1994b) Singlet oxygen production in thylakoid membranes during photoinhibition as detected by EPR spectroscopy. Photosynth Res 39:191-199

Hirakawa K, Hirano T, Nishimura Y, Arai T, Nosaka Y (2011) Control of singlet oxygen generation photosensitized by meso-Anthrylporphyrin through interaction with DNA. Photochem Photobiol 87:833-839

Iermak I, Szabo M, Zavafer A (2020) Special issue in honour of Prof. Reto J. Strasser - Analysis of OJIP transients during photoinactivation of Photosystem II indicates the presence of multiple photosensitizers in vivo and in vitro. Photosynthetica 58(2):497-506. https://doi.org/10.32615/ps.2019.166

Jones LW, Kok B (1966) Photoinhibition of chloroplast reactions. I Kinetics and Action Spectra. Plant Physiol 41:1037-1043

Kale R, Hebert AE, Frankel LK, Sallans L, Bricker TM, Pospíšil $P$ (2017) Amino acid oxidation of the D1 and D2 proteins by oxygen radicals during photoinhibition of Photosystem II. Proc Natl Acad Sci 114(11):2988-2993. https://doi.org/10.1073/ pnas. 1618922114

Keren N, Berg A, van Kan PJM, Levanon H, Ohad I (1997) Mechanism of Photosystem II photoinactivation and D1 protein degradation at low light: The role of back electron flow. Proc Natl Acad Sci USA 94:1579-1584

Kodru S, Rehman AU, Vass I (2020) Chloramphenicol enhances Photosystem II photodamage in intact cells of the cyanobacteriumSynechocystisPCC 6803. Photosynth Res 145(3):227-235. https://doi.org/10.1007/s11120-020-00784-1

Komenda J, Sobotka R, Nixon PJ (2012) Assembling and maintaining the Photosystem II complex in chloroplasts and cyanobacteria. Curr Opin Plant Biol 15:245-251

Kou J, Oguchi R, Fan D-Y, Chow WS (2012) The time course of photoinactivation of Photosystem II in leaves revisited. Photosynth Res 113:157-164

Kovács L, Kálai T, Tandori J, Kós PB, Hideg É (2014) Assessing the applicability of singlet oxygen photosensitizers in leaf studies. Photochem Photobiol 90:129-136

Krasnovsky AA (1998) Singlet molecular oxygen in photobiochemical systems: IR phosphorescence studies. Mol Cel Biol 12:665-690

Krieger-Liszkay A (2005) Singlet oxygen production in photosynthesis. J Exp Bot 56:337-346

Krieger-Liszkay A, Fufezan C, Trebst A (2008) Singlet oxygen production in Photosystem II and related protection mechanism. Photosynth Res 98:551-564

Leisinger U, Rüfenacht K, Fischer B, Pesaro M, Spengler A, Zehnder AJB, Eggen RIL (2001) Plant Mol Biol 46 (4): 395-408. https:// doi.org/https://doi.org/10.1023/a:1010601424452

Li L, Aro EM, Millar AH (2018) Mechanisms of photodamage and protein turnover in photoinhibition. Trends Plant Sci 23(8):667-676. https://doi.org/10.1016/j.tplants.2018.05.004

Lima-Melo Y, Alencar VTCB, Lobo AKM, Sousa RHV, Tikkanen M, Aro E-M, Silveira JAG, Gollan PJ (2019) Photoinhibition of Photosystem I provides oxidative protection during imbalanced photosynthetic electron transport in Arabidopsis thaliana. Front Plant Sci 10:916. https://doi.org/10.3389/fpls.2019.00916

Lingvay M, Akhtar P, Sebok-Nagy K, Pali T, Lambrev PH (2020) Photobleaching of chlorophyll in light-harvesting complex II increases in lipid environment. Front Plant Sci 11:14. https://doi.org/10. 3389/fpls.2020.00849 
Lupínková L, Komenda J (2004) Oxidative modifications of the Photosystem II D1 protein by reactive oxygen species: from isolated protein to cyanobacterial cells. Photochem Photobiol 79:152-162

Macpherson AN, Telfer A, Barber J, Truscott TG (1993) Direct detection of singlet oxygen from isolated Photosystem II reaction centres. Biochim Biophys Acta 1143:301-309

Matheson IBC, Lee J (1979) Chemical-reaction rates of amino-acids with singlet oxygen. Photochem Photobiol 29(5):879-881. https:// doi.org/10.1111/j.1751-1097.1979.tb07786.x

Méndez-Hurtado J, López R, Suárez D, Menéndez MI (2012) Theoretical study of the oxidation of histidine by singlet oxygen. Chem Eur J 18:8437-8447

Mishra NP, Francke C, van Gorkom HJ, Ghanotakis DF (1994) Destructive role ofsinglet oxygen during earobic illuminatin of the Photosystem II core complex. Biochim Biophys Acta 1186:81-90

Miyao M (1994) Involvement of active oxygen species in degradation of the D1 protein under strong illumination in isolated subcomplexes of Photosystem II. Biochemistry 33:9722-9730

Murata N, Allakhverdiev SI, Nishiyama Y (2012) The mechanism of photoinhibiton in vivo: re-evaluation of the roles of catalase, a-tocopherol, non-photochemical quenching, and electron transport. Biochim Biophys Acta 1817:1127-1133

Murata N, Nishiyama Y (2018) ATP is a driving force in the repair of Photosystem II during photoinhibition. Plant Cell Environ 41(2):285-299. https://doi.org/10.1111/pce.13108

Nishiyama Y, Allakhverdiev SI, Murata N (2006) A new paradigm for the action of reactive oxygen species in the photoinhibition of Photosystem II. Biochim Biophys Acta 1757:742-749

Nishiyama Y, Allakhverdiev SI, Yamamoto H, Hayashi H (2004) Singlet oxygen inhibits the repair of Photosystem II by suppressing the translation elongation of the D1 protein in Synechocystis sp. PCC 6803. Biochemistry 43:11321-11330

Nishiyama Y, Yamamoto H, Allakhverdiev SI, Inaba H, Yokota A, Murata N (2001) Oxidative stress inhibits the repair of photodamage to the photosynthetic machinery. EMBO J 20:5587-5594

Nixon PJ, Michoux F, Yu J, Boehm M, Komenda J (2010) Recent advances in understanding the assembly and repair of Photosystem II. Ann Bot 106:1-16

Ogilby PR (2010) Singlet oxygen: there is indeed something new under the sun. Chem Soc Rev 39(8):3181-3209. https://doi.org/10.1039/ B926014P

Oguchi R, Douwstra P, Fujita T, Chow WS, Terashima I (2011) Intraleaf gradients of photoinhibition induced by different color lights: implications for the dual mechanisms of photoinhibition and for the application of conventional chlorophyll fluorometers. New Phytol. https://doi.org/10.1111/j.1469-8137.2011.03669.x:1-14

Oguchi R, Terashima I, Chow WS (2009) The involvement of dual mechanisms of photoinactivation of Photosystem II in Capsicum annuum L. plants. Plant Cell Physiol 50:1815-1825

Ohad I, Kyle DJ, Arntzen CJ (1984) Membrane protein damage and repair: removal and replacement of inactivated 32-kilodalton polypeptides in chloroplast membranes. J Cell Biol 99:481-485

Ohnishi N, Allakhverdiev SI, Takahashi S, Higashi S, Watanabe M, Nishiyama Y, Murata N (2005) Two-step mechanism of photodamage to Photosystem II: step 1 occurs at the oxygen-evolving complex and step 2 occurs at the photochemical reaction center. Biochemistry 44:8494-8499

Okada K, Satoh K, Katoh S (1991) Chloramphenicol is an inhibitor of photosynthesis. FEBS Lett 295:155-158

Pospísil P (2009) Production of reactive oxygen species by Photosystem II. Biochim Biophys Acta 1787:1151-1160

Pospísil P (2012) Molecular mechanisms of production and scavenging of reactive oxygen species by Photosystem II. Biochim Biophys Acta 1817:218-231
Rehman AU, Cser K, Sass L, Vass I (2013) Characterization of singlet oxygen production and its involvement in photodamage of Photosystem II in the cyanobacterium Synechocystis PCC 6803 by histidine-mediated chemical trapping. Biochim Biophys Acta 1827:689-698

Rehman AU, Kodru S, Vass I (2016a) Chloramphenicol mediates superoxide production in Photosystem II and enhances its photodamage in isolated membrane particles. Front Plant Sci 7:5. https://doi.org/10.3389/fpls.2016.00479

Rehman AU, Szabó M, Deák Z, Sass L, Larkum A, Ralph P, Vass I (2016b) Symbiodinium sp. cells produce light-induced intra-and extracellular singlet oxygen, which mediates photodamage of the photosynthetic apparatus and has the potential to interact with the animal host in coral symbiosis. New Phytol 212(2):472-484

Renger G, Govindjee (1985) The mechanism of photosynthetic water oxidation. Photosynth Res 6:33-55

Rinalducci S, Pedersen JZ, Zolla L (2004) Formation of radicals from singlet oxygen produced during photoinhibition of isolated lightharvesting proteins of Photosystem II. Biochim Biophys Acta 1608:63-73

Rinalducci S, Pedersen JZ, Zolla L (2008) Generation of reactive oxygen species upon strong visible light irradiation of isolated phycobilisomes from Synechocystis PCC 6803. Biochim Biophys Acta 1777:417-424

Schreiber U, Quayle P, Schmidt S, Escher BI, Mueller JF (2007) Methodology and evaluation of a highly sensitive algae toxicity test based on multiwell chlorophyll fluorescence imaging. Biosens Bioelectron 22(11):2554-2563. https://doi.org/10.1016/j.bios. 2006.10.018

Sedoud A, Lopez-Igual R, Rehman AU, Wilson A, Perreau F, Boulay C, Vass I, Krieger-Liszkay A, Kirilovsky D (2014) The cyanobacterial photoactive orange carotenoid protein is an excellent singlet oxygen quencher. Plant Cell 26(4):1781-1791

Shoaf WT, Lium BW (1976) Improved extraction of chlorophyll-a and chlorophyll-b from algae using dimethyl-sulfoxide. Limnol Oceanogr 21(6):926-928. https://doi.org/10.4319/lo.1976.21.6. 0926

Skovsen E, Snyder JW, Lambert JDC, Ogilby PR (2005) Lifetime and diffusion of singlet oxygen in a cell. J Phys Chem B 109:8570-8573

Sonoike K, Terashima I (1994) Mechanism of photosystem-I photoinhibition in leaves of Cucumis sativus L. Planta 194:287-293

Sonoike K, Terashima I, Iwaki M, Itoh S (1995) Destruction of photosystem I iron-sulfur centers in leaves of Cucumis sativus L. by weak illumination at chilling temperatures. FEBS Lett 362:235-238

Suorsa M, Jarvi S, Grieco M, Nurmi M, Pietrzykowska M, Rantala M, Kangasjarvi S, Paakkarinen V, Tikkanen M, Jansson S, Aro EM (2012) Proton gradient regulation-5 is essential for proper acclimation of arabidopsis photosystem I to naturally and artificially fluctuating light conditions. Plant Cell 24(7):2934-2948. https:// doi.org/10.1105/tpc.112.097162

Telfer A, Oldham TC, Phillips D, Barber J (1999) Singlet oxygen formation detected by near-infrared emission from isolated Photosystem II reaction centres: direct correlation between P680 triplet decay and luminescence rise kinetics and its consequences for photoinhibition. J Photochem Photobiol B 48:89-96

Tiwari A, Mamedov F, Grieco M, Suorsa M, Jajoo A, Styring S, Tikkanen M, Aro EM (2016) Photodamage of iron-sulphur clusters in photosystem I induces non-photochemical energy dissipation. Nat Plants 2(4):9. https://doi.org/10.1038/nplants.2016.35

Treves H, Raanan H, Kedem I, Murik O, Keren N, Zer H, Berkowicz SM, Giordano M, Norici A, Shotland Y, Ohad I, Kaplan A (2016) The mechanisms whereby the green alga Chlorella ohadii, isolated from desert soil crust, exhibits unparalleled photodamage 
resistance. New Phytol 210(4):1229-1243. https://doi.org/10. $1111 /$ nph. 13870

Triantaphylidès C, Havaux M (2009) Singlet oxygen in plants: production, detoxification and signaling. Trends Plant Sci 14(4):219228. https://doi.org/10.1016/j.tplants.2009.01.008

Tyystjärvi E (2013) Photoinhibition of Photosystem II. In: Jeon K (ed) International review of cell and molecular biology, 1st edn. Academic Press, Elsevier Inc., pp 243-303

Tyystjarvi E, Aro EM (1996) The rate constant of photoinhibition, measured in lincomycin-treated leaves, is directly proportional to light intensity. Proc Natl Acad Sci USA 93:2213-2218

Tyystjarvi T, Herranen M, Aro E-M (2001) Regulation of translation elongation in cyanobacteria: membrane targeting of the ribosome nascent-chain complexes controls the synthesis of D1 protein. Mol Microbiol 40(2):476-484. https://doi.org/10.1046/j.1365-2958. 2001.02402.x

Vass I (2011) Role of charge recombination processes in photodamage and photoprotection of the Photosystem II complex. Physiol Plant 142:6-16

Vass I, Cser K (2009) Janus-faced charge recombinations in Photosystem II photoinhibition. Trends Plant Sci 14:200-205

Virtanen O, Khorobrykh S, Tyystjärvi E (2021) Acclimation of chlamydomonas reinhardtii to extremely strong light. Photosynth Res 147(1):91-106. https://doi.org/10.1007/s11120-020-00802-2
Zavafer A, Iermak I, Cheah MH, Chow WS (2019) Two quenchers formed during photodamage of phostosystem II and the role of one quencher in preemptive photoprotection. Sci Rep 9:9. https:// doi.org/10.1038/s41598-019-53030-7

Zavafer A, Koinuma W, Chow WS, Cheah MH, Mino H (2017) Mechanism of photodamage of the oxygen evolving Mn cluster of Photosystem II by excessive light energy. Sci Rep 7:8. https://doi.org/ 10.1038/s41598-017-07671-1

Zhou Y, Liu Z, Yao M, Chen J, Xiao Y, Han G, Shen J-R, Wang F (2021) Elucidating the molecular mechanism of dynamic photodamage of Photosystem II membrane protein complex by integrated proteomics strategy. CCS Chem 443-454. https://doi.org/https:// doi.org/10.31635/ccschem.021.202000583

Zolla L, Rinalducci S (2002) Involvement of active oxygen species in degradation of light-harvesting proteins under light stresses. Biochemistry 41:14391-14402

Publisher's Note Springer Nature remains neutral with regard to jurisdictional claims in published maps and institutional affiliations. 